\title{
Small Number of Big Banks: An Overview of Recent Mergers in Indian Banking Sector
}

\author{
${ }^{1}$ Dr. Sapna Kasliwal, Asst. Professor Commerce \\ Shri Rajendra Suri Govt, College, Sardarpur-Rajgarh (M.P) \\ ${ }^{2}$ Dr. Dilip Kumar Gupta, Asst. Professor Commerce \\ Swami Vivekanand Govt. College, Sarangpur (M.P)
}

\begin{abstract}
:
Government of India with its vision to create globally competitive banks has initiated the consolidation of smaller PSB's in bigger entities. The merger of five regional banks with State Bank of India and merger of two Public Sector Banks (PSBs) Dena and Vijaya with Bank of Baroda in recent past (2019) followed by mega consolidation plan of merging ten public sector banks into four banks is an indication of direction of the wind is going to blow for Indian banking industry. This policy of consolidation is an important tool used by banks for corporate restructuring and is in line with reformist agenda pursued by Govt of India (GOI) since 1990. These entities are to receive recapitalization funds from GOI to boost their net-worth strengthening their capital base. The present research is conducted to understand the objectives and statistics behind these mergers.
\end{abstract}

Keywords: Merger, Mega Consolidation Plan, Financial Inclusion, Big Banks

\section{Introduction:}

In a bid to make Indian banks globally competitive where bank size is important; a need is felt to undertake business process reengineering, and redefine their strategy and organisation structure to survive under these competitive condition $\{$ Kamath K. V. Shenoy, P.S Kumar Ranjana, Nayak RM and Ravichandran N (2003) $\}$ and to turn them from conventional to next gen banks, the largest ever merger: with each amalgamated entity having business of over Rs 8 lakh crore: in the public sector banking space in India took place on April 1, 2020. As per the mega consolidation plan six Public Sector Banks were merged into four large banks resulting in total number of public sector banks in the country came down to 12 from 18. The exercise assumed significance as it took place at a time when the entire country is under the grip of COVID-19 outbreak followed by complete lockdown for almost 3 months. At such a crucial time it was being assumed that merger may not remain easy and transitional phase seem to be difficult. However, as per the heads of the anchor banks though pandemic situation has created some issues still merger process with certain minor changes has gone smoothly. This is an attempt of govt of India to boost economic through creation of fewer and stronger global sized banks. In other word's M\&A's is a strategic tool for expanding their horizon as well as survival of the weak banks by merging into larger banks. M\&As as corporate events helps an organization to create synergy and provide sustainable competitive advantage. \{ Goyal

\section{K.A. \& Joshi Vijay (2011) \}}

Following the consolidation, there are now seven large public sector banks (PSBs), and five smaller ones. There were as many as 27 PSBs in 2017. Customers, including depositors of the merging banks, will now be treated as customers of the banks in which they have merged. 
In addition, consolidation would also provide impetus to merged entities by increasing their ability to support larger ticket-size lending and have competitive operations by virtue of greater financial capacity. Following are the banks that were merged in April,2020:

\begin{tabular}{|l|l|}
\hline Head/Anchor Bank & Merged Bank \\
\hline $\begin{array}{l}\text { Punjab National } \\
\text { Bank }\end{array}$ & $\begin{array}{l}\text { Punjab National } \\
\text { Bank } \\
\text { Oriental Bank of } \\
\text { Commerce } \\
\text { United Bank of India }\end{array}$ \\
\hline Canara Bank & $\begin{array}{l}\text { Canara Bank } \\
\text { Syndicate Bank }\end{array}$ \\
\hline Union Bank of India & $\begin{array}{l}\text { Union Bank of India } \\
\text { Andhra Bank } \\
\text { Corporation Bank }\end{array}$ \\
\hline Indian Bank & $\begin{array}{l}\text { Indian Bank } \\
\text { Allahabad Bank }\end{array}$ \\
\hline
\end{tabular}

Apart from these 10 merged entities, six banks will continue to work individually viz Bank of India, Central Bank of India, Indian Overseas Bank, UCO bank, Bank of Maharashtra, Punjab and Sind Bank.

\section{Literature Review:}

\section{Mehta Jay and Kakani Ram Kumar} (2006) stated that M\&A in the Indian Banking are an important necessity as the fragmented nature of the Indian banking sector resulted in poor global competitive presence and position.Revathy S.(2011) through her case study of merged banks concluded that merger or larger size is just a facilitator but no guarantee for improved profitability on a sustained basis. Hence the thrust should be on improving risk management capabilities, corporate governance and strategic business planning. Khan Ahmed Azeem (2011) in his research proved that merged banks can obtain efficiency and growth through M\&A's and passes the benefits to the equity shareholders in the form of dividend.
Sinha Pankaj \& Gupta Sushant (2011) and Antony Akhil (2011), in their respective analysis found that there is significant positive difference in profitability ratios of banks in the post -merger scenario. Same has been confirmed by Dutta and Dawn (2012) in their studies in which they concluded that post-merger periods were successful and saw a significant increase in total assets, profits, revenue, deposits, and in the number of employees of the acquiring firms of the banking industry in India whereas Devarajappa S. (2012) concluded merger effect is helpful for survival of week Bank by merging into larger banks. Similarly,

Patel Ritesh (2015) examined finance and stock return of selected banks to know the effect after merger and concluded that merger and acquisition has positively impacted on Indian banks. Ghosh Sangita (2016) researched on merger between Global Trust Bank and Oriental Bank of Commerce and found that after merging bank profitability and efficiency of acquirer bank has improved but there was no change in liquidity position of oriental bank of commerce.

\section{Research Gap:}

From the above study of various research papers, it is quite empirical that mergers have always been part and parcel of Indian Banking Sector and is an area which continually attract researchers keeping an eye on Indian Banking scenario. The present research is an attempt to study the latest mega consolidation plan of merging ten public sector banks into four banks in order to enhance financial performance of commercial banks by achieving economies of scale, managerial synergies, global outreach and increased market share.

\section{Objectives of the Study:}

Being the largest amalgamation in history of Indian Banking Industry it again triggered the importance of mergers and attracts attention towards following objectives:

1) To study the objectives behind these mergers. 
2) To under the merger statistics of the merged banks.

\section{Research Methodology}

The study has been based majorly on Secondary data. Secondary data was collected from various publications and websites of RBI, Indian Banker's Association, websites of acquirer and target bank, various research papers and books. These data were based on historical accounting concept, and as such its findings depend entirely on the accuracy of such data.

\section{Objectives behind the mergers:}

The mega merger of banks was executed as per the consolidation plan of GoI. The Finance Ministry opined that repositioning PSB's through these mergers will help India make a USD 5 Trillion Economy. Basically following are the government's objective behind the merger of these banks:

1. Small number of big banks with enhanced capacity to increase credit.

2. Banks with increased branch networks will have Banks with a strong national presence and international reach.
3. Reduction in lending cost.

4. Unlocking potential through consolidation through creation of Next Generation technology for the banking sector.

5. Operational efficiency gains to reduce cost of lending.

6. Improved ability to raise market resources.

7. Enhanced risk appetite.

8. Wider offerings with enhanced customization.

9. Better ability to raise resources from market.

\section{The Merger Statistics:}

As mentioned earlier this mega consolidation scheme lead to major change in Indian Banking Structure. According to the Government this decision of making large entities will make the Indian banks capable of meeting the higher funding needs of the economy and will help in acquiring the global scale. After merger process following is the status of PSB's working in India as per their business size, branch network and market share:

\begin{tabular}{|c|c|c|c|c|c|}
\hline $\begin{array}{c}\text { Acquirer/ Head } \\
\text { Bank }\end{array}$ & Merged Banks & Business Size & PSB Size & Market Size & $\begin{array}{c}\text { Branch } \\
\text { Network }\end{array}$ \\
\hline $\begin{array}{l}\text { State Bank of } \\
\text { India }\end{array}$ & Merged Earlier & $\begin{array}{l}\text { 52.65 Lakh } \\
\text { crore }\end{array}$ & $1^{\text {st }}$ largest bank & 22.5 & 23561 \\
\hline $\begin{array}{c}\text { Punjab } \\
\text { National Bank }\end{array}$ & $\begin{array}{c}\text { Punjab } \\
\text { National Bank } \\
\text { Oriental Bank } \\
\text { of Commerce } \\
\text { United Bank of } \\
\text { India }\end{array}$ & $\begin{array}{l}\text { 17.94 Lakh } \\
\text { crore }\end{array}$ & $2^{\text {nd }}$ largest bank & 7.7 & $\begin{array}{c}12236 \text { (Post } \\
\text { Merger) }\end{array}$ \\
\hline Bank of Baroda & Merged Earlier & $\begin{array}{l}\text { 16.13 Lakh } \\
\text { crore }\end{array}$ & $3^{\text {rd }}$ largest bank & 7 & 9836 \\
\hline Canara Bank & $\begin{array}{c}\text { Canara Bank } \\
\text { Syndicate Bank }\end{array}$ & $\begin{array}{l}\text { 15.20 Lakh } \\
\text { crore }\end{array}$ & $4^{\text {th }}$ largest Bank & 6.6 & $\begin{array}{c}\text { 10,994(Post } \\
\text { Merger) }\end{array}$ \\
\hline $\begin{array}{c}\text { Union Bank of } \\
\text { India }\end{array}$ & $\begin{array}{c}\text { Union Bank of } \\
\text { India } \\
\text { Andhra Bank } \\
\text { Corporation } \\
\text { Bank }\end{array}$ & $\begin{array}{l}\text { 14.59 Lakh } \\
\text { crore }\end{array}$ & $5^{\text {th }}$ largest Bank & 6.3 & $\begin{array}{l}\text { 9,951 (Post } \\
\text { Merger) }\end{array}$ \\
\hline
\end{tabular}




\begin{tabular}{|c|c|c|c|c|c|}
\hline Bank of India & $\begin{array}{c}\text { Work } \\
\text { Individual0ly }\end{array}$ & $\begin{array}{l}\text { 9.03 Lakh } \\
\text { Crore }\end{array}$ & $6^{\text {th }}$ largest Bank & 3.9 & 5,350 \\
\hline Indian Bank & $\begin{array}{c}\text { Indian Bank } \\
\text { Allahabad } \\
\text { Bank }\end{array}$ & 8.08 Lakh crore & $7^{\text {th }}$ largest Bank & 3.5 & $\begin{array}{l}6364 \text { (Post } \\
\text { Merger) }\end{array}$ \\
\hline $\begin{array}{c}\text { Central Bank } \\
\text { of India }\end{array}$ & $\begin{array}{c}\text { Work } \\
\text { Individually }\end{array}$ & 4.68 Lakh crore & \multirow{5}{*}{\multicolumn{2}{|c|}{$\begin{array}{l}\text { Comparatively Small Banks with } \\
\text { more regional concentration. }\end{array}$}} & 4779 \\
\hline $\begin{array}{c}\text { Indian } \\
\text { Overseas Bank }\end{array}$ & $\begin{array}{c}\text { Work } \\
\text { Individually }\end{array}$ & 3.75 Lakh crore & & & 3339 \\
\hline UCO Bank & $\begin{array}{c}\text { Work } \\
\text { Individually }\end{array}$ & 3.17 Lakh crore & & & 3137 \\
\hline $\begin{array}{c}\text { Bank of } \\
\text { Maharashtra }\end{array}$ & $\begin{array}{c}\text { Work } \\
\text { Individually }\end{array}$ & 2.34 Lakh crore & & & 1914 \\
\hline $\begin{array}{c}\text { Punjab \& Sind } \\
\text { Bank }\end{array}$ & $\begin{array}{c}\text { Work } \\
\text { Individually }\end{array}$ & 1.71 Lakh crore & & & 1575 \\
\hline
\end{tabular}

Source: ToI dt Aug 31, 2019

From the analysis of above table, it is quite obvious that out of the twelve banks remaining in public sector; six banks have gone through the merger while six banks are still working individually. Out of these remaining, only Bank of India has larger market size while Central Bank of India, Indian Overseas Bank, UCO bank, Bank of Maharashtra and Punjab and Sind Bank are comparatively smaller ones with limited geographical reach.

\section{Merger of Punjab National Bank, Oriental Bank of Commerce and United Bank into Punjab National Bank:}

From the above table it is clear that this plan has led Punjab National Bank as $2^{\text {nd }}$ Largest Bank both in terms of business and branch network. Merger of Oriental Bank of Commerce and United Bank into Punjab National Bank has created a bank with ₹17.94 lakh crore business and 12,236 branches extending its geographical presence.

\section{Swap Ratio:}

Every shareholder of OBC and United Bank of India will get 1,150 shares and 121 shares of PNB, for every 1,000 shares of the particular bank. The face value of PNB is Rs 2 per share whereas face value of OB.C and United Bank of India is Rs 10/share each.

\begin{tabular}{|l|l|l|l|l|}
\hline Head & $\begin{array}{l}\text { Punjab } \\
\text { National Bank }\end{array}$ & $\begin{array}{l}\text { Oriental Bank } \\
\text { of Commerce }\end{array}$ & $\begin{array}{l}\text { United Bank of } \\
\text { India }\end{array}$ & $\begin{array}{l}\text { Amalgamated } \\
\text { Bank }\end{array}$ \\
\hline $\begin{array}{l}\text { Total } \\
\text { Business (in } \\
\text { crore Rs) }\end{array}$ & $11,82,226$ & $4,04,194$ & $2,08,106$ & $17,94,526$ \\
\hline $\begin{array}{l}\text { Gross } \\
\text { Advances (in } \\
\text { crore Rs) }\end{array}$ & $4,71,827.72$ & $1,57,958.67$ & $67,523.33$ & $7,97,309.72$ \\
\hline $\begin{array}{l}\text { Deposits (in } \\
\text { crore Rs) }\end{array}$ & $7,03,846.32$ & $2,30,108.23$ & $1,37,614.64$ & $10,71,569.19$ \\
\hline CASA Ratio & $42.97 \%$ & $30.61 \%$ & $50.91 \%$ & $41.49 \%$ \\
\hline $\begin{array}{l}\text { Domestic } \\
\text { Branches }\end{array}$ & 7,175 & 2,814 & 2,049 & 11,437 \\
\hline
\end{tabular}




\begin{tabular}{|l|l|l|l|l|}
\hline PCR & $61.72 \%$ & $56.53 \%$ & $51.17 \%$ & $59.59 \%$ \\
\hline Employees & 68,781 & 21,729 & 13,804 & $1,00,649$ \\
\hline
\end{tabular}

From the above table it is quite obvious that merger is a big win for customers of Oriental Bank of Commerce and United Bank of India as the amalgamated bank will have a wider geographical reach through 11,000 plus branches, more than 13,000 ATMs, one lakh employees and a business mix of over Rs 17 lakh crore to serve their customers effectively and efficiently. CASA ratio which reflects bank's saving and demand deposits and is an important indicator of bank's financial health seems to be improved in the amalgamated bank. The gross advances and gross deposits of both the United bank and Oriental Bank of Commerce were less on the date of merger and this merger will definitely be beneficial for their customers as they will be associated with a larger Bank, having a widespread pan-India network and better capital base and have access to enhanced efficient products, credit facilities and best of banking services.

\section{Merger of Canara Bank and Syndicate Bank into Canara Bank}

The merger of Syndicate Bank with Canara Bank has created the fourth largest public sector bank with ₹15.20 lakh crore business and a branch network of 10,324. Canara Bank has Rs 10.4 lakh crore and Syndicate Bank has Rs 4.7 lakh crore in business.

\section{Swap Ratio}

For Syndicate Bank's merger into Canara Bank, the share swap is 158 equity shares of Canara Bank for every 1,000 equity shares of Syndicate Bank.

\begin{tabular}{|c|c|c|c|}
\hline Head & Canara Bank & Syndicate Bank & Amalgamated Bank \\
\hline $\begin{array}{c}\text { Total Business } \\
\text { (in crore Rs) }\end{array}$ & $10,43,249$ & $4,77,046$ & $15,20,295$ \\
\hline $\begin{array}{c}\text { Gross Advances } \\
\text { (in crore Rs) }\end{array}$ & $4,32,175.20$ & $1,84,398.78$ & $6,16,573.98$ \\
\hline $\begin{array}{c}\text { Deposits (in } \\
\text { crore Rs) }\end{array}$ & $6,25,351.17$ & $2,81,269.82$ & $9,06,620.99$ \\
\hline CASA Ratio & $31.37 \%$ & $33.47 \%$ & $30.21 \%$ \\
\hline $\begin{array}{c}\text { Domestic } \\
\text { Branches }\end{array}$ & 6,634 & 4,291 & 10,925 \\
\hline PCR & $41.48 \%$ & $48.83 \%$ & $44.32 \%$ \\
\hline Employees & 58,629 & 30,381 & 89,010 \\
\hline
\end{tabular}

Both of these banks operate predominantly in South and this merger will benefit both by cost reduction due to network overlap, similar operating atmosphere to enable smoothen consolidation process and more income opportunities for Joint Ventures and Subsidiaries. The new amalgamated unit is large in size with extended geographical reach and is extensively working on grass-rooting banking, customer delight, and satisfaction. The merged bank shall enormously enhance the reach of banking services to the larger public to derive the benefit of size, scale and strength and augment the financial inclusion activities currently underway. From the above table it is quite obvious that this 
merger is also a big win for customers of Canara Bank and Syndicate Bank of India as the amalgamated bank will have a wider geographical reach through 10,000 plus branches, near about ninety thousand employees and a business mix of over Rs 15 lakh crore to serve their customers effectively and efficiently.

\section{Merger of Union Bank of India, Andhra Bank and Corporation Bank into Union Bank of India:}

Merger of Andhra Bank and Corporation Bank with Union Bank of India has created India's fifth largest public sector bank with ₹14.59 lakh crore business and 9,951 branches.

\section{Swap Ratio:}

As Andhra Bank and Corporation Bank merged with Union Bank of India, shareholders of Andhra Bank and Corporation Bank got 325 and 330 shares, respectively, of Union Bank of India for every 1,000 shares of their respective banks, according to the exchange filing. The face value of Union Bank of India and Andhra Bank is Rs 10 per share each while par value of Corporation Bank stands at Rs 2 per share.

\begin{tabular}{|l|l|l|l|l|}
\hline Head & $\begin{array}{l}\text { Union } \\
\text { Bank }\end{array}$ & Andhra Bank & $\begin{array}{l}\text { Corporation } \\
\text { Bank }\end{array}$ & $\begin{array}{l}\text { Amalgamated } \\
\text { Bank }\end{array}$ \\
\hline $\begin{array}{l}\text { Total Business } \\
\text { (in crore Rs) }\end{array}$ & $7,41,307$ & $3,98,511$ & $3,19,616$ & $14,59,434$ \\
\hline $\begin{array}{l}\text { Gross Advances } \\
\text { (in crore Rs) }\end{array}$ & $3,15,049.41$ & $1,57,742.33$ & $1,27,399.06$ & $6,00,190.80$ \\
\hline $\begin{array}{l}\text { Deposits (in } \\
\text { crore Rs) }\end{array}$ & 450668.45 & 212609.38 & 205354.78 & 868632.61 \\
\hline CASA Ratio & $50.92 \%$ & $34.54 \%$ & $30.57 \%$ & $38.67 \%$ \\
\hline PCR & $58.27 \%$ & $68.62 \%$ & $66.60 \%$ & $63.07 \%$ \\
\hline Employees & 37,318 & 20,364 & 18,486 & 76,168 \\
\hline Branches & 4438 & 2961 & 2552 & 9951 \\
\hline
\end{tabular}

The amalgamation strengthened the bank's footprint in southern India with considerable market share in this region. It is also expected to generate cost and revenue synergies through rationalisation of branches and savings on technology on the combined entity to the tune of Rs 2,500 crore over the next three years. Execution of all the processes under merger happened without much disturbance to customers and employees of Andhra Bank and Corporation Bank.

The combined entity has more than 9,500 branches and 12,000 ATMs across the country and of the 9,500 branches, 700 plus branches will be rationalised because of the proximity resulting in less operating cost. The capital adequacy ratio of the combined entity will be at $12.5-13$ per cent, while gross NPAs and net NPAs stand at 14 per cent and below 6 per cent, respectively.

The amalgamation will create an employee base of 75,000, of which 37,000 are from Andhra Bank and Corporation Bank put together.

\section{Merger of Indian Bank and Allahabad Bank into Indian Bank:}

The merger of Allahabad Bank with Indian Bank has created the seventh largest public sector bank with ₹8.08 lakh crore business having strong branch networks in the south, north and east of the country. 


\section{Swap Ratio:}

115 equity shares of Rs 10.00 each of Indian Bank (transferee bank) for every 1,000 (one thousand) equity shares of Rs 10.00 each of Allahabad Bank (transferor bank).

\begin{tabular}{|c|c|c|c|}
\hline & Indian Bank & Allahabad Bank & Amalgamated Bank \\
\hline $\begin{array}{c}\text { Total Business (in } \\
\text { crore Rs) }\end{array}$ & $\mathbf{4 , 2 9 , 9 7 2}$ & $\mathbf{3 , 7 7 , 8 8 7}$ & $\mathbf{8 , 0 7 , 8 5 9}$ \\
\hline $\begin{array}{c}\text { Gross Advances (in } \\
\text { crore Rs) }\end{array}$ & $\mathbf{1 , 9 7 , 8 8 7 . 0 1}$ & $\mathbf{1 , 4 2 9 6 4 . 7 8}$ & $\mathbf{3 , 4 0 , 8 5 1 . 7 9}$ \\
\hline $\begin{array}{c}\text { Deposits (in crore } \\
\text { Rs) }\end{array}$ & $\mathbf{2 , 6 0 , 2 2 5 . 9 0}$ & $\mathbf{2 , 2 8 , 6 0 8 . 5 1}$ & $\mathbf{4 , 8 8 , 5 3 4 . 4 1}$ \\
\hline CASA Ratio & $\mathbf{3 4 . 6 4 \%}$ & $\mathbf{4 7 . 8 2 \%}$ & $\mathbf{4 1 . 2 3} \%$ \\
\hline Domestic Branches & $\mathbf{2 , 9 5 3}$ & $\mathbf{3 , 4 1 0}$ & $\mathbf{6 , 3 6 3}$ \\
\hline PCR & $49.13 \%$ & $74.15 \%$ & $66.21 \%$ \\
\hline Employees & $\mathbf{1 8 , 6 9 1}$ & $\mathbf{2 3 , 3 5 6}$ & $\mathbf{4 2 , 0 4 7}$ \\
\hline
\end{tabular}

All branches of Allahabad Bank started functioning as branches of Indian Bank following the merger plan as per the RBI's directives. This merger with the rich legacy of Indian Bank of 113 years and Allahabad Bank of 155 years provides a great base to serve customer pan India. PostMerger created an institution with sound financial strength and nationwide connectivity consisting of 6,000-plus branches, 4,800-plus ATMs, 42000plus employees serving 120 million-plus customers and business mix of over Rs $8 \mathrm{Cr} /$ Tillion with significant improvement in CASA and PCR ratio. The complementary branch presence shall add to Indian Bank's network in the northern, central and eastern states and the 120 million-plus customers of both the banks will benefit from a wider geographical reach. The integration lead to drive operational, revenue and cost synergies to banks. The increased lending capacity shall be utilised to serve Corporate and MSME clientele. Customers of both shall have access to a wider range of products and services.

\section{Some Other Important Ratios to be Considered:}

CRAR of Banks- Pre and Post Merger

\begin{tabular}{|l|l|c|c|c|c|}
\hline & Merged Banks & $\begin{array}{c}\text { March31, } \\
\mathbf{2 0 2 0} \\
\text { (Pre-Merger) }\end{array}$ & $\begin{array}{c}\text { June 30, } \\
\mathbf{2 0 2 0} \\
\text { (Post } \\
\text { Merger) }\end{array}$ & $\begin{array}{c}\text { Sept 30, } \\
\mathbf{2 0 2 0} \\
\text { (Post } \\
\text { Merger) }\end{array}$ & $\begin{array}{c}\text { Dec 31, } \\
\mathbf{2 0 2 0} \\
\text { ( Post } \\
\text { Merger) }\end{array}$ \\
\hline 1 & Punjab National Bank & 14.14 & & & \\
& Oriental Bank of & 11.55 & 12.63 & 12.84 & $13.88 \mathrm{~S}$ \\
& Commerce & 5.56 & & & \\
\hline
\end{tabular}




\begin{tabular}{|c|c|c|c|c|c|}
\hline 2 & $\begin{array}{l}\text { Canara Bank } \\
\text { Syndicate Bank }\end{array}$ & $\begin{array}{l}13.65 \\
11.52\end{array}$ & 12.77 & 12.77 & 13.69 \\
\hline 3 & $\begin{array}{l}\text { Union Bank of India } \\
\text { Andhra Bank } \\
\text { Corporation Bank }\end{array}$ & $\begin{array}{l}12.81 \\
11.12 \\
11.53\end{array}$ & 11.62 & 12.33 & 12.98 \\
\hline 4. & $\begin{array}{l}\text { Indian Bank } \\
\text { Allahabad Bank }\end{array}$ & $\begin{array}{l}14.12 \\
12.01\end{array}$ & 13.45 & 13.64 & 14.06 \\
\hline
\end{tabular}

The reason minimum capital adequacy ratios (CARs) to Capital to RisK Weighted Assets Ratio (CRAR) are critical is to make sure that banks have enough cushion to absorb a reasonable amount of losses. The capital adequacy ratios ensure the efficiency and stability of a nation's financial system by lowering the risk of banks becoming insolvent. Generally, a bank with a high capital adequacy ratio is considered safe and likely to meet its financial obligations. From the analysis of above table we can conclude that there seems to improvement in CRAR post merger. However, it may happen that in long duration it will increase.

\begin{tabular}{|c|c|c|c|c|c|}
\hline \multicolumn{6}{|c|}{ NNPA Ratio of Banks- Pre and Post Merger } \\
\hline \multicolumn{6}{|r|}{ In Percent } \\
\hline & Name of the Bank & $\begin{array}{c}\text { March31, } \\
2020 \\
\text { (Pre- } \\
\text { Merger) }\end{array}$ & $\begin{array}{c}\text { June 30, } \\
2020 \\
\text { (Post } \\
\text { Merger) }\end{array}$ & $\begin{array}{c}\text { Sept 30, } \\
2020 \\
\text { (Post } \\
\text { Merger) }\end{array}$ & $\begin{array}{c}\text { Dec 31, } \\
2020 \\
\text { (Post } \\
\text { Merger) }\end{array}$ \\
\hline 1. & $\begin{array}{l}\text { Punjab National Bank } \\
\text { Oriental Bank of Commerce } \\
\text { United Bank }\end{array}$ & $\begin{array}{l}5.78 \\
5.00 \\
4.88\end{array}$ & 5.39 & 4.75 & 4.03 \\
\hline 2. & $\begin{array}{l}\text { Canara Bank } \\
\text { Syndicate Bank }\end{array}$ & $\begin{array}{l}4.18 \\
4.61\end{array}$ & 4.08 & 3.42 & 2.64 \\
\hline 3. & $\begin{array}{l}\text { Union Bank of India } \\
\text { Andhra Bank } \\
\text { Corporation Bank }\end{array}$ & $\begin{array}{l}5.49 \\
4.92 \\
5.14 \\
\end{array}$ & 4.97 & 4.13 & 3.27 \\
\hline 4. & $\begin{array}{l}\text { Indian Bank } \\
\text { Allahabad Bank }\end{array}$ & $\begin{array}{l}3.13 \\
5.66\end{array}$ & 3.76 & 2.96 & 2.35 \\
\hline
\end{tabular}

NNPA is the acronym for net non-performing assets and high non- performing assets are not favourable for a bank. High NPAs mean that banks have too many loans that have become nonfunctional or are not rendering any interest income to the bank. From the analysis of above table we can find that there is significant difference in NNPA of banks in post- merger period as nnpa of banks reduced significantly in post-merger period. 
ROA Ratio of Banks- Pre and Post Merger

\begin{tabular}{|c|c|c|c|c|c|}
\hline \multicolumn{6}{|c|}{ ROA Ratio of Banks- Pre and Post Merger } \\
\hline & \multicolumn{5}{|r|}{ In Percent } \\
\hline & Merged Banks & $\begin{array}{c}\text { March 31, } \\
2020 \\
\text { (Pre-Merger) }\end{array}$ & $\begin{array}{c}\text { June 30, } \\
2020 \\
\text { (Post } \\
\text { Merger) }\end{array}$ & $\begin{array}{c}\text { Sept 30, } \\
2020 \\
\text { (Post } \\
\text { Merger) }\end{array}$ & \begin{tabular}{|c|} 
Dec 31, \\
2020 \\
( Post \\
Merger)
\end{tabular} \\
\hline 1 & $\begin{array}{l}\text { Punjab National Bank } \\
\text { Oriental Bank of } \\
\text { Commerce } \\
\text { United Bank }\end{array}$ & $\begin{array}{r}0.04 \\
-0.83 \\
-4.17\end{array}$ & 0.09 & 0.19 & 0.15 \\
\hline 2 & $\begin{array}{l}\text { Canara Bank } \\
\text { Syndicate Bank }\end{array}$ & $\begin{array}{l}-0.32 \\
-1.20\end{array}$ & 0.16 & 0.16 & 0.24 \\
\hline 3 & $\begin{array}{l}\text { Union Bank of India } \\
\text { Andhra Bank } \\
\text { Corporation Bank }\end{array}$ & $\begin{array}{l}-0.53 \\
-0.50 \\
-1.13\end{array}$ & 0.12 & 0.15 & 0.19 \\
\hline 4. & $\begin{array}{l}\text { Indian Bank } \\
\text { Allahabad Bank }\end{array}$ & $\begin{array}{l}0.26 \\
-2.22\end{array}$ & 0.25 & 0.28 & 0.35 \\
\hline
\end{tabular}

Return on assets (ROA) ratio shows how efficiently a firm is using its assets to generate profit and thus how profitable a company is relative to its assets. An analysis of the above table shows that there is significant improvement in ROA of merged banks in the post- merger period especially in case of Canara Bank and Union Bank of India as their negative ROA of pre -merger period has turned into positive ROA in post-merger period.

\section{Benefits of Banking Merger}

1. To speed up the economic development of the country and to turn India into a 5 trillion economy big funded projects will be the prerequisite which can only be fulfilled by financial inclusion and creating big banks with global presence. With this motive, the present mega consolidation plan was executed to broaden the geographical reach of regionally concentrated banks to inflate their coverage.
2. The objectives of financial inclusion and broadening the geographical reach of banking can be achieved better with the merger of large public sector banks and leveraging on their expertise. The merger will help the geographically concentrated regionally present banks to expand their coverage.

3. These mergers lead to increased lending capacity and strong balance sheet. This enhanced size of the bank will help the merged banks to increase their operational efficiency, and to offer better customer services through more diversified more products and services and thus help in cohesive expansion of the banking sector.

4. These mergers would help in better capital management by making them comparatively big banks to compete globally with greater recognition and higher performance rating. Also with enlarged capital base it will be easier for banks to 
maintain their short and long term liquidity leading to reduced burden on RBI and central govt. to recapitalize these banks again and again.

5. Small number of big banks instead of large number of small banks is one of the basic motives behind these mergers. Especially the banks who were underperforming can easily survive using this strategy keeping their customer trust intact. With the large scale expertise available in every sphere of banking operation, the scale of inefficiency which is more in case of small banks, will be minimized. Bank staff of smaller banks will also get benefits as of large scale bank staff specially relating to wage disparity and service conditions. In short, weaker bank gets merged into stronger one and gets the benefit of large-scale operations

\section{Conclusion:}

Government ownership, similar pay structure and career progression avenues for staff and Common Core banking solution are some factors which helped removing the hurdles from the way of consolidation and helped smoothen the operationalization of the merger. Merger and acquisition acts as strategic tool for the augmentation and expansion of Indian Banking Sector seem to be no exception. The merged entities can now reap the benefits of synergy special in case of branch network presence across regions. For example, United Bank of India which had a large presence in the region will now benefit from the more diversified branch network of Punjab National Bank which had vast network in the northern and central region. Similarly, before the merger since the Indian bank with the concentrated presence in the southern part of the country, can now expand its reach in central and southern part due to its alliance with the Allahabad bank. Mergers had strengthened the capital buffers of the bank that were facing challenges in meeting regulatory requirements.

\section{$\underline{\text { Refrences }}$}

1. Antony Akhil, K. (2011), "Post-Merger Profitability of Selected Banks in India,"International Journal of Research in Commerce, Economics and Management.

2. Dash Ashutosh (2005), "The post - merger performance Puzzle: An evaluation of long term profitability of Indian firms ", The ICFAI Journal of Accounting Research, January 2015, pp.no. 6-22.

3. Ghosh Alok (2001), "Does Operating Performance really Improve following Corporate acquisitions?" Journal of corporate Finance, Vol.7, pp.151-178.

4. Ghosh Sangita (2016), "Merger Between Global Trust Bank and Oriental Bank of Commerce" Business Spectrum, July -Dec2016, Vol VI No.2.

5. Goyal Dr. K.A. \& Joshi Vijay (2011), "Mergers in Banking Industry of India: Some Emerging Issues", Asian Journal of Business and Management Sciences, ISSN: 2047-2528.

6. Goyal Dr. K.A. \& Joshi Vijay (2012), "Merger and Acquisition in Banking Industry: A Case Study of ICICI Bank Ltd", International Journal of Research in Management, ISSN 2249-5908.

7. Kamath K V, Kohli S S, Shenoy P S, Ranjana Kumar, Nayak R M, and Kuppuswamy PT, N Ravichandran, "Indian Banking Sector: Challenges and Opportunities", Vikalpa, Vol. 28, No.3, Jul-Sept. 2003.

8. Khan Ahmad Azeem (2011), "Merger and Acquisitions (M\&As) in the Indian Banking Sector in Post Liberalization Regime", International Journal of Contemporary Business Studies, ISSN 2156-7506.

9. Madan Mohan Dutta and Suman Kumar Dawn. (2012), "Merger and Acquisitions in Indian Banks after Liberalization: An Analysis," Indian Journal of Commerce and Management Studies.

10. Kakani, Ram Kumar and Mehta, Jay, Motives for Mergers and Acquisitions in the Indian Banking Sector - A Note on Opportunities \& Imperatives (November 2006). SPJCM Singapore Working Paper No. 06-13, Available at SSRN: https://ssrn.com/abstract=1008717 or http://dx.doi.org/10.2139/ssrn.1008717 
11. Prajapati Sadhana (2010)," Mergers and Acquisitions in the Indian Banking Sector: An Overview ", ISSN- 0974-2832.

12. Patel, Ritesh, Pre-Merger and Post-Merger Financial \& Stock Return Analysis: A Study with Reference to Selected Indian Banks (June 10, 2015). Asian Journal of Research in Banking and Finance, Vol. 4, No. 12, December 2014, pp. 1-9., Available at SSRN: https://ssrn.com/abstract=2616587

13. Revathy S. (2011), "Mergers And Acquisitions In The Indian Banking Sector - Financial Implications "Namex International Journal of Management Research,

14. Raiyani Jagdish R (2010)," Effect of mergers on efficiency and productivity of Indian banks: A CAMELS analysis", Asian Journal of Management Research, ISSN 2229 - 3795.

15. S.Devarajappa (2012), "Mergers in Indian Banks: A Study on Mergers of HDFC Bank Ltd. And Centurion Bank of Punjab Ltd." International Journal of Marketing, Financial Services \& Management Research, ISSN 2277 3622.

16. Selvam, M. (2007), Mergers and Acquisitions in the Banking Sector- The Indian Scenario. S.Viswanathan (Printers \& Publishers) Pvt. Ltd.

17. Sinha Pankaj \& Gupta Sushant. (2011), "Mergers and Acquisitions: A Pre-Post Analysis for the Indian Financial Services Sector".

18. Published annual reports of bidder and target banks.

19. RBI's Annual Publication Reports

20. RBI's Statistical Tables Time Series Data

\section{Newspapers and Magazines':}

1. The Economic Times, Mumbai

2. Times of India, New Delhi

3. India Today

4. Money Today

5. Business Standard

6. Financial Chronicle

7. Business Bhaskar

8. The Hindu Business Line

9. DNA

10. Rajasthan Patrika

11. Business World

12. Business Week
13. Jagran josh

\section{Websites}

1. www.businesstoday.intoday.in

2. www.bis.org_ ( Bank for International Settlements )

3. www.finmin.nic.in ( Finance Ministry of India )

4. www.iba.org.in_ ( Indian Banking Association )

5. www.planningcommission.nic.in]

6. www.financialstability board.org

7. www.shodhganga.inflibnet.ac.in 